\title{
Mixotrophic and heterotrophic nanoflagellate grazing in the convergence zone east of New Zealand
}

\author{
Karl A. Safi*, Julie A. Hall \\ National Institute of Water and Atmospheric Research, PO Box 11-115, Hamilton, New Zealand
}

\begin{abstract}
Nanoflagellate grazing was investigated in the subtropical convergence region off the east coast of the South Island, New Zealand, in the summer of 1995. Clearance rates were estimated using $0.5 \mu \mathrm{m}$ fluorescently labelled beads and fluorescently labelled bacteria to represent bacterial populations and $1.0 \mu \mathrm{m}$ fluorescently labelled beads representing picophytoplankton populations. Nanoflagellate grazing by mixotrophs was on average lower than heterotrophic nanoflagellate clearance rates per individual for all prey types, and both heterotrophic and mixotrophic nanoflagellates showed a preference for picophytoplankton-sized particles over bacteria-sized particles when grazing on artificial prey. Despite lower clearance rates per individual, higher numbers of mixotrophic nanoflagellates meant that they contributed $57 \%$ of measured grazing impact on picophytoplankton-sized particles, $40 \%$ of grazing on bacteria-sized particles and $55 \%$ of grazing on stained bacteria per day. In addition to assessing grazing rates, by identifying the major genera involved we were able to distinguish the predominate grazers in 3 water masses and investigate how changes in species composition may be linked to grazing in this region.
\end{abstract}

KFY WORDS: Nanoflagellates $\cdot$ Mixotrophy $\cdot$ Grazing $\cdot$ Autotrophy $\cdot$ Heterotrophy $\cdot$ Microbial food web

\section{INTRODUCTION}

The flow of carbon within the microbial food web has been the focus of many studies since the introduction of the concept of the microbial loop by Azam et al. (1983). This concept has resulted in an upsurge of interest in the role of plankton $<200 \mu \mathrm{m}$ in size. Heterotrophic nanoflagellates (HNF) and ciliated protists are now considered the primary grazers of bacteria and picophytoplankon and are largely responsible for making energy from these sources available to higher trophic levels (Porter et al. 1985).

The importance of HNF within the microbial loop has led to further investigation into the role of nanoflagellates as a group. Nanoflagellates are flagellates that fall within the size range 2 to $20 \mu \mathrm{m}$ and consist of 3 major groups; HNF, which graze on other living

\footnotetext{
•E-mail: k.safi@niwa.cri.nz
}

cells, autotrophic nanoflagellates (ANF), which are photosynthetic, and mixotrophic nanoflagellates (MNF), which are defined in this study as organisms which are capable of combining both photosynthesis and grazing (phagosizing) particles (Sanders 1991). Reviews of mixotrophy in both freshwater and marine environments report highly variable clearance rates among different MNF populations (Borass et al. 1988, Sanders \& Porter 1988, Sanders 1991, Jones 1994) but suggest that MNF can be important grazers on bacteria and picophytoplankton, especially in oligotrophic waters.

Sanders et al. (1990) and Jones (1994) both propose that nanoflagellates can occur anywhere on a continuum from complete heterotrophy to complete phototrophy, with the degree of either process depending on both the species and the environmental conditions. Nutrient limitation has been shown to stimulate mixotrophic grazing in some cases (Sibbald \& Albright 1991, Rothhaupt 1996b). Facultative heterotrophy has 
also been reported within marine flagellates, and some photosythetic species of nanoflagellates such as Ochromonas have also been shown to switch to heterotrophy when they are light limited (Sibbald \& Albright 1991. Rothhaupt 1996a). Mixotrophic grazing on phosphorus-rich bacteria in a phosphorus-limited environment has even been found to induce nitrogen limitation in the mixotrophic species (Jansson et al. 1996). Despite such examples of facultative heterotrophy, in most cases the reason for a population to change its source of nutrition remains unclear, with mixotrophy providing different benefits for different species and groups (Jones 1994). Three main reasons for the development of mixotrophy have been proposed. These suggest that heterotrophy may provide a source of (1) carbon (Bird \& Kâlff 1986); (2) inorganic nutrients (Salonen \& Jokinen 1988); and (3) organic nutrients essential for growth such as vitamins and essential amino acids (Caron et al. 1991). Overall, the occurrence of mixotrophy can be viewed as a competitive strategy to deal with the planktonic environment, which is subject to rapid temporal and spatial variations.

The impact of MNF grazing is recognised as important and in some cases makes up a substantial part of the overall grazing on bacteria and picophytoplankton populations (Sanders et al. 1989, Berninger et al. 1991a, Hall et al. 1993). Grazing by MNF has already been investigated in New Zealand waters during winter and autumn periods (Hall et al. 1993, James et al. 1996); these studies have indicated that the contribution by MNF can be significant. Hall et al. (1993) reported mean clearance rates by phytoflagellates of $1.1 \mathrm{nl}$ ind. ${ }^{-1} \mathrm{~h}^{-1}$ on bacteria-sized prey and $0.5 \mathrm{nl} \mathrm{ind}^{-1}$ $\mathrm{h}^{-1}$ on picophytoplankton-sized prey off the west coast of the South Island in winter. James et al. (1996) reported mean clearance rates of $0.11 \mathrm{nl}$ ind. ${ }^{-1} \mathrm{~h}^{-1}$ on bacteria-sized prey and $0.8 \mathrm{nl}$ ind.$^{-1} \mathrm{~h}^{-1}$ on picophytoplankton-sized prey during autumn in both west and east coast waters off the South Island. These studies indicate both spatial and seasonal variability in the clearance rates of MNF.

In winter or autumn, nutrients are rarely considered limiting to phyloplankton growth; however, during the summer, inorganic nutrients are often low and are likely to be limiting to growth. This study was aimed at assessing the role of nanotlagellate grazing during this period with a special focus on the role of mixotrophic species. In addition, we aimed to identify the major genera and predominant grazers in the 3 water masses and investigate how changes in species composition may be linked to grazing in this region. The study was conducted in the subtropical, convergence and subantarctic waters of the subtropical convergence region off the east coast of the South Island (Fig. 1).

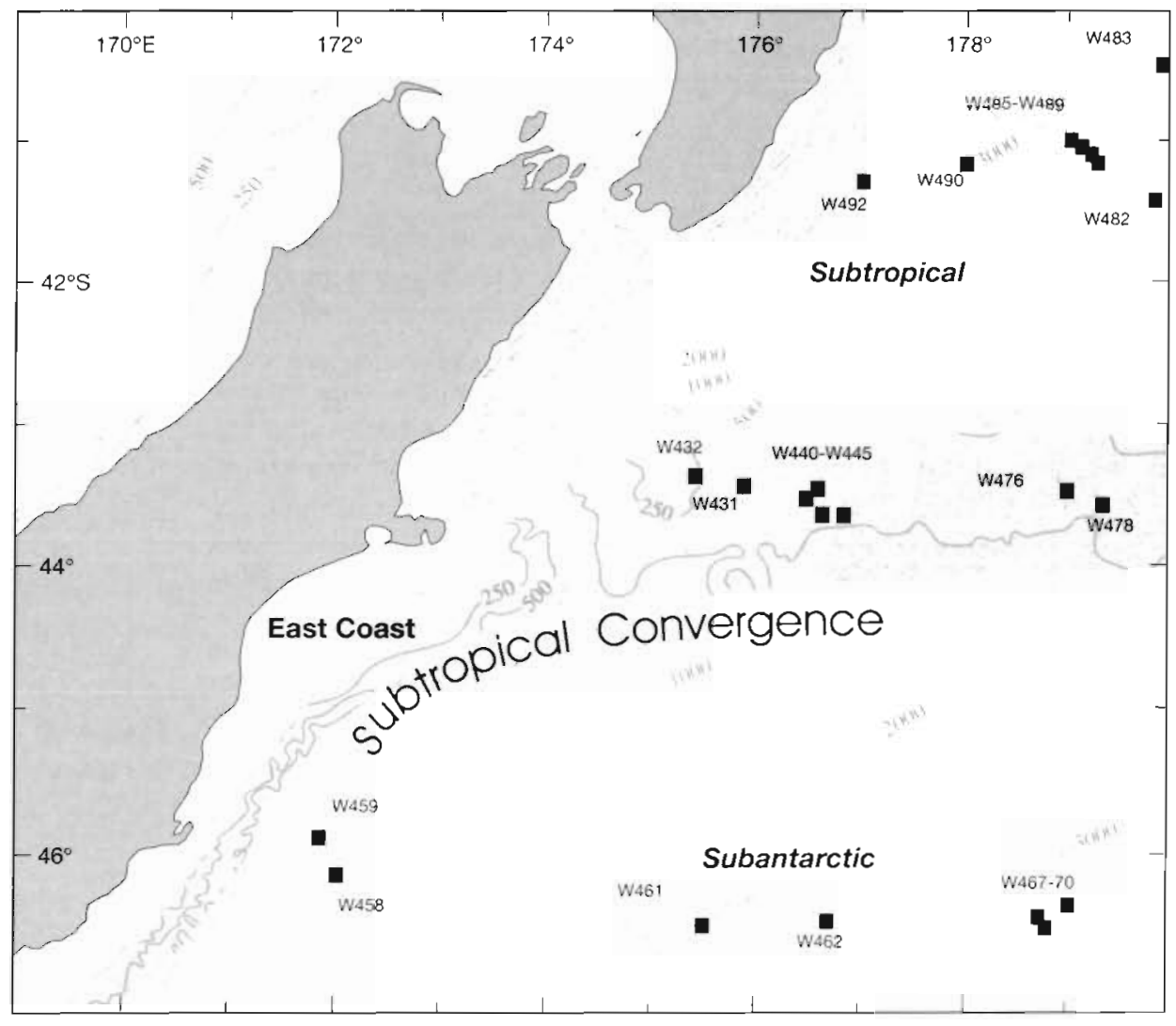

Fig. 1. Location map identifying the 3 major water masses sampled and the approximate location of sampling sites 


\section{METHODS}

General sampling. Samples for grazing experiments were collected at 30 stations from the RV 'Giljanes' during voyage 3024 across the Chatham Rise in late summer of 1995. The Chatham Rise was selected because within this relativity small geographic zone, we were able to assess populations and clearance rates in subtropical, convergence and subantarctic water masses (Fig. 1). The convergence zone is a region where cool, nutrient-rich, subantarctic waters of the Southern Ocean meet warmer, nutrient-poor, subtropical waters (Heath 1985).

Eight stations were sampled in the subtropical and convergence water masses and 7 in the subantarctic water mass on 2 transects across the convergence zone between 19 February and 5 March 1995 (Fig. 1). Water samples for biological and chemical analysis were collected at selected depths, in and below the mixed layer with 5 and 101 Niskin bottles. At each station conductivity, temperature and density profiles were recorded using a Seabird 9/11 CTD profiler. Conductivity was calibrated using a Guildline Autosal Laboratory Salinometer Model 8400A.

Subsamples of water from 6 to 8 depths were filtered through acid washed Whatman GF/F filters for nutrient analysis. Ammonia $\left(\mathrm{NH}_{4}-\mathrm{N}\right)$, nitrate $\left(\mathrm{NO}_{3}-\mathrm{N}\right)$ and dissolved reactive phosphorus (DRP) concentrations were measured using the analytical methods described in Vincent et al. (1991). For measurement of chlorophyll a (chl a), $500 \mathrm{ml}$ subsamples were filtered onto Whatman GF/F filters which were frozen in liquid nitrogen and kept stored frozen until analysed. Chl a was subsequently extracted using $90 \%$ acetone, with fluorescence being measured by a Perkin Elmer LS 50 B spectrofluorometer (Strickland \& Parsons 1972).

Planktonic abundance. Bacterial and picophytoplankton numbers were determined by direct counts at all sampling depths. Twenty millilitre subsamples for bacterial enumeration were fixed with $1 \mathrm{ml}$ of formalin, and refrigerated in the dark for a maximum of $24 \mathrm{~h}$. A $5 \mathrm{ml}$ subsample was stained with acridine orange for $5 \mathrm{~min}$, and filtered onto prestained $0.2 \mu \mathrm{m}$ Nuclepore filters (Hobbie et al. 1977). Bacteria were counted under blue light excitation using a Leitz compound microscope (BP 450 to $490 \mathrm{~nm}$ excitation, LP 515 barrier filter, RPK 510 dichromatic beam splitter). Samples for picophytoplankton enumeration were passed through a $2 \mu \mathrm{m}$ Nuclepore pre-filter before being fixed with $1 \mathrm{ml}$ of paraformaldehyde $(0.2 \%$ final concentration) for at least $1 \mathrm{~h}$. Duplicate $50 \mathrm{ml}$ subsamples were then filtered onto pre-dyed $0.2 \mu \mathrm{m}$ Nuclepore filters which were then mounted in a gelatin/glycerol mix, sealed onto glass slides and frozen (Hall 1991). Enumeration of eukaryotic picophytoplankton was con- ducted under blue light excitation (BP 450 to $490 \mathrm{~nm}$ excitation, LP 515 barrier filter, RPK 510 dichromatic beam splitter), resulting in a red fluorescence from $\mathrm{chl} a$. Enumeration of prokaryotic picophytoplankton was conducted under green light excitation (BP 530 to $560 \mathrm{~nm}$ excitation, LP 580 barrier filter, RPK 580 dichromatic beam splitter), resulting in an orange fluorescence from phycoerythrin.

Samples collected for nanoflagellate enumeration were size fractionated through a $20 \mu \mathrm{m}$ nylon mesh The filtrate was then fixed 1:1 with ice-cold glutaraldehyde ( $2 \%$ final concentration) for 1 h (Sanders et al. 1989). Fixed samples were filtered onto prestained $0.8 \mu \mathrm{m}$ black Nuclepore filters, stained for 5 min with $2 \mathrm{ml}$ primulin, rinsed with $2 \mathrm{ml}$ Tris $\mathrm{HCl}$, mounted on slides and stored frozen (Bloem et al. 1986). Nanoflagellates were counted under UV excitation using a Leica compound microscope (BP 450 to $490 \mathrm{~nm}$ excitation, LP 520 barrier filter, FT 510 dichromatic beam splitter). Photosynthetic (plastidic) nanoflagellates were differentiated by chl a fluorescing red under blue light excitation (BP 450 to $490 \mathrm{~nm}$ excitation, LP 515 barrier filter, RPK 510 dichromatic beam splitter). Forty randomly selected fields were counted per filter. Nanoflagellate biovolumes were calculated using dimensions and approximated geometric shape (Chang 1988). Biovolumes were calculated from measurements on a minimum of 200 cells, collected at $10 \mathrm{~m}$ from all stations. Biovolumes were then combined and averaged within each water mass to give an average biovolume per water mass. Samples for ciliate enumeration were preserved in Lugol's iodine ( $1 \%$ final concentration) and enumerated in Utermöhl chambers with a Leica inverted microscope (James \& Hall 1998).

Cell carbon estimates were based on those used by Li et al. (1992); for bacteria $20 \mathrm{fg} \mathrm{C} \mathrm{cell}^{-1}$, and for picophytoplankton $250 \mathrm{fg} \mathrm{C} \mathrm{cell}^{-1}$. A carbon to chl a conversion factor of 50 was used to convert chl a biomass to carbon (Banse 1982).

Bacterial productivity was measured by the incorporation of [methyl ${ }^{3} \mathrm{H}$ ] thymidine into bacterial DNA following the method of Wicks \& Robarts (1987). Sizefractionated primary production was assessed during simulated on-deck $24 \mathrm{~h}$ incubations using ${ }^{14} \mathrm{C}$ as described in Hawes et al. (1997).

For taxonomic evaluation of the nanoflagellate population, slides prepared for the assessment of grazing were examined using epiflorescence. Six stations within each water mass were selected at random. Nanoflagellates were identified by a number of characteristic features and then grouped into classes based on these criteria. Characteristic features included criteria such as: cell size, shape; presence or absence of chloroplasts; chloroplast colour (fluorescence), num- 
ber, size, type and position of flagellum; presence or absence of haptonema. Where possible, identification was taken to species level using the criteria described in Fenchel (1982a), Sournia (1986), Patterson \& Larson (1991), Throndsen (1993). The methodology was not designed to be comprehensive, given that preserved cells are difficult to identify, due to a lack of motility, distortions in shape and cell damage, including loss of flagellum from some individuals. For these reasons, the use of epifluorescence combined with compound microscopy could only provide an indicative analysis of nanoflagellate composition.

Grazing experiments. Fluorescent microspheres, 0.5 and $1.0 \mu \mathrm{m}$ in diameter (Polysciences Inc., Warrington, PA), were used to simulate bacteria- and picophytoplankton-sized particles, respectively. Under blue light excitation (BP 450 to $490 \mathrm{~nm}$ excitation, LP 515 barrier filter, RPK 510 dichromatic bearn splitter), $0.5 \mu \mathrm{m}$ microspheres fluoresced a bright yeliow-green and $1.0 \mu \mathrm{m}$ microspheres fluoresced bright red. Microspheres were added to the sample to give bacteria- and picophytoplankton-sized particle concentrations of $5 \times 10^{5}$ and $1 \times 10^{5} \mathrm{ml}^{-1}$, respectively. This resulted in an average bacteria to bead ratio of $\sim 5.0$, which corresponds to an average tracer concentration of $19 \%$ of the bacterial population. Although higher than reported in some studies (Christoffersen 1994), this is lower or similar to the tracer concentration used in other studies (Sanders et al. 1989, Marrase et al. 1992, Hall et al. 1993). Due to an initial overestimate of picophytoplankton numbers, the concentration of picophytoplankton-sized particles was, however, on average 5 times higher than the observed natural picophytoplankton populations. This induced a prey-saturated environment as described by Fenchel (1982b). In such an environment, prey uptake rate becomes independent of population density and is limited by the ingestion rate (Fenchel 1982b). Although this is not ideal and may lead to an overestimate of the uptake rate in the natural environment, it still provides a useful measure of the grazing potential of nanoflagellates on picophytoplankton populations in these waters.

To reduce clumping and minimise selection by nanoflagellates against artificial particles, all microspheres were soaked overnight in bovine serum albumin (10 $\mathrm{mg} \mathrm{ml}^{-1}$ ) (James et al. 1996). Samples were sonicated at $30 \mathrm{~W}$ power level for four, $2 \mathrm{~s}$ bursts using a Misonix XL2020 sonicator (Pace \& Bailiff 1987).

Fluorescently labelled bacteria (FLB) were also used in grazing experiments. Monospecific cultures of Escherichia coli were grown in sterile media and then centrifuged in a Sorvall RC26 centrifuge at $15000 \mathrm{rpm}$ $(22000 \times g)$ for $20 \mathrm{~min}$, and the pellet was then suspended in $10 \mathrm{ml}$ of phosphate-buffered saline solution (0.05 $\mathrm{M} \mathrm{Na}_{2} \mathrm{HPO}_{4}$, at ambient salinity adjusted to
$\mathrm{pH}$ 7.6). Two milligrams of 5-(4,6-dichorotriazin-2-yl) aminofluorescein (DTAF) (Sigma Chemical Co., St. Louis, MO) were added to the cell suspension which was then incubated in a waterbath for $2 \mathrm{~h}$ at $60^{\circ} \mathrm{C}$. After incubation, the cells were centrifuged and washed 3 times with the phosphate-buffered saline solution to remove excess DTAF fluorescein. After the final wash, the cells were resuspended in $20 \mathrm{ml}$ of $0.02 \mathrm{M}$ tetrasodium pyrophosphate $\left(\mathrm{PP}_{\mathrm{i}}\right)-\mathrm{NaCl}$ solution. These solutions were stored frozen until used as described by Sherr et al. (1987). The concentration of bacteria in the solution was determined using the bacterial enumeration methods described earlier. Subsamples of the solution were thawed and sonicated at $30 \mathrm{~W}$ power level for four, $2 \mathrm{~s}$ bursts prior to use. FLB were added to give a final concentration of $5 \times 10^{5} \mathrm{ml}^{-1}$.

FLB varied in size from 0.3 to $2.0 \mu \mathrm{m}(\sim 0.8 \mu \mathrm{m}$ average size); the natural bacterial population was less variable in size and was on average $-0.5 \mathrm{pm}$ in diameter. It is likely that this size difference between FLB and the natural bacterial population would have influenced clearance rates through size selectivity (Gonzales et al. 1990). However, other factors such as chemosensory responses (Sherr et al. 1987, Landry et al. 1991) and predator size (Havskum \& Hansen 1997) also influence selectivity. Taking these factors into consideration and recognising that the size of FLB did not represent either type of fluorescently labelled bead, it was decided that clearance rates on FLB related more closely to the bacterial population and therefore were compared to clearance on $0.5 \mu \mathrm{m}$ bacteria-sized fluorescently labelled beads.

Grazing experiments using FLB and both sizes of artificial prey were conducted at 7 stations within each water mass, from 3 selected depths above and below the deep chl a maxima. Subsamples of $300 \mathrm{ml}$ were poured gently into $500 \mathrm{ml}$ polycarbonate bottles and then placed in an on-deck incubator under shade cloth to approximate irradiance at the depth of the sample for $30 \mathrm{~min}$ to allow the assemblage to recover from handling. Solutions of either microspheres or FLB were added, and $75 \mathrm{ml}$ subsamples for evaluation of nanoflagellate grazing taken at 0 and 20 min. Subsamples were fixed 1:1 with ice-cold glutaraldehyde ( $2 \%$ final concentration) for $1 \mathrm{~h}$ (Sanders et al. 1989). Duplicate samples were filtered onto $2.0 \mu \mathrm{m}$ Nuclepore filters and the filters were stained as previously described for nanoflagellate enumerations. Ingested beads were counted under blue light excitation with a minimum of 100 consumed beads per filter being enumerated. Phototrophic nanoflagellates were distinguished from HNF by the chl a fluorescence under blue light excitation. The mean number of beads phagosized per individual for both HNF and MNF populations was calculated. This result was in turn used to estimate total 
grazing rates for both $\mathrm{HNF}$ and $\mathrm{MNF}$, taking into account the ambient prey populations.

\section{RESULTS}

\section{General features of water masses}

In the waters off the east coast of the South Island of New Zealand, the late-summer mixed layer depth was similar for subantarctic and subtropical waters, with means of 41 and $40 \mathrm{~m}$, respectively. The mixed layer in the convergence waters was shallower, with a mean of $34 \mathrm{~m}$. Nitrate concentrations in the mixed layer of the subtropical and convergence waters were low in contrast to the subantarctic waters (Table 1). Chl a concentrations were similar in all 3 water masses, ranging from 0.06 to $0.86 \mathrm{mg} \mathrm{m}^{-3}$ (Table 1). In subtropical waters, 50 to $60 \%$ of the chl a in the mixed layer was in the size fraction 0.2 to $2 \mu \mathrm{m}$ i.e. picophytoplankton; in subantarctic waters, 30 to $40 \%$, and in convergence waters the contribution ranged between 30 and $60 \%$.

\section{Planktonic abundance}

Bacterial numbers were relatively similar in all water

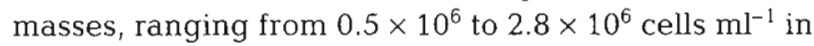
subantarctic waters, $0.6 \times 10^{6}$ to $4.0 \times 10^{6} \mathrm{cells} \mathrm{ml}^{-1}$ in

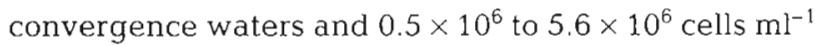
in subtropical waters (Table 1, Fig. 2). Bacterial carbon dominated the carbon pool with ratios of bacterial carbon to phytoplankton carbon at $10 \mathrm{~m}$ of $4.5: 1$ in convergence waters, 2.8:1 in subantarctic waters and 2.7:1 in subtropical waters. Bacterial productivity measured by [methyl- ${ }^{3} \mathrm{H}$ ] thymidine produced daily mean growth rates of $9 \%$ in subantarctic, $12 \%$ in convergence and $16 \%$ in subtropical waters.

Prokaryotic picophytoplankton numbers were more variable across the 3 water masses and were approximately 2 orders of magnitude lower than bacterial numbers. Prokaryotic picophytoplankton numbers ranged from $0.2 \times 10^{4}$ to $4.9 \times 10^{4}$ cells $\mathrm{ml}^{-1}$ in subantarctic waters, $0.2 \times 10^{4}$ to $10.5 \times 10^{4}$ cells ml $\mathrm{m}^{-1}$ in convergence waters and $0.4 \times 10^{4}$ to $9.1 \times 10^{4} \mathrm{cells} \mathrm{ml}^{-1}$ in subtropical waters (Table 1, Fig. 2). Primary productivity measured by ${ }^{14} \mathrm{C}$ uptake in the $<2 \mu \mathrm{m}$ size fraction produced daily mean growth rates of $54 \%$ in subantarctic, $58 \%$ in convergence and $70 \%$ in subtropical waters. Eukaryotic picophytoplankton numbers were not reported as they represented only a small proportion of $<2 \mu \mathrm{m}$ biomass and were near or below the detection limits of the enumeration method.

HNF numbers ranged from 71 to 857 cells $\mathrm{ml}^{-1}$ in subantarctic waters, 138 to 782 cells $\mathrm{ml}^{-1}$ in convergence waters and 95 to 693 cells $\mathrm{ml}^{-1}$ in subtropical waters (Table 1, Fig. 2). Phototrophic nanoflagellate numbers were, however, more variable within each water mass, ranging from 336 to 1728 cells $\mathrm{ml}^{-1}$ in subantarctic waters, 156 to 2542 cells $\mathrm{ml}^{-1}$ in convergence waters and 153 to 957 cells $\mathrm{ml}^{-1}$ in subtropical waters (Table 1 , Fig. 2). Within subantarctic and convergence waters all genera identified were found to possess the ability to graze. For this reason, although not every individual within these genera grazed, we decided to regard all phototrophic nanoflagellates in these water masses as MNF for analysis purposes. Within subtropical waters, however, 3 genera representing $\sim 10 \%$ of the phototrophic nanoflagellate population were not observed to ingest prey during our experiments. In this water mass we regarded $90 \%$ of the phototrophic nanoflagellates as MNF and adjusted all grazing calculations accordingly.

HNF biovolume was approximately twice MNF biovolume in all water masses, which was opposite to the general trend reported previously in this region for winter and spring seasons (James \& Hall 1996, Safi \& Hall 1997). HNF biovolumes were similar between convergence and subtropical waters, with a mean biovolume at $10 \mathrm{~m}$ of 37.7 and 

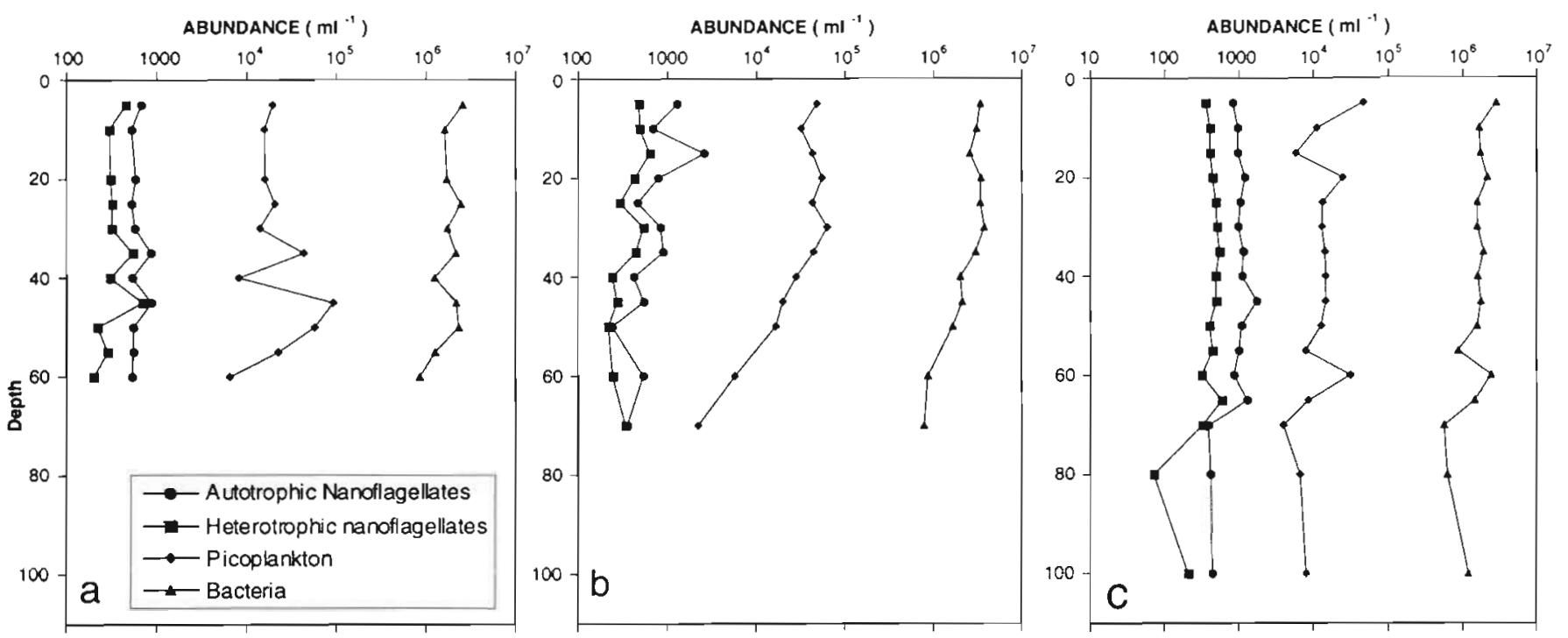

Fig. 2. Depth profiles of micro-organism abundance $\left(\mathrm{ml}^{-1}\right)$ in (a) subtropical waters, (b) convergence waters, and (c) subantarctic waters

$37.4 \mu^{3}$, respectively. Similar genera were observed in these 2 water masses, with Kinetoplastidea and Chrysophyceae dominating and Choanoflagellidea also present (Throndsen 1993, Patterson \& Larson 1991). In subantarctic waters, however, HNF biovolumes were considerably larger, with a mean biovolume of $57.4 \mu^{3}$. This was due to the presence of larger colourless dinophyceans in addition to genera of Kinetoplastidea and Chrysophyceae.

A similar trend in biovolume was found for MNF populations in all 3 water masses with pyrmnesiophyceans, Chrysochromulina sp. and Imantonia sp. (Chretiennot-Dinet et al. 1990, Throndsen 1993) identified as the dominant genera. An average biovolume for MNF of 14.7 and $17.1 \mu^{3}$ was reported at $10 \mathrm{~m}$ in convergence waters and subtropical waters, respectively. Subtropical waters were distinguished by the presence of euglenophyceans including Eutreptiella sp. (Chretiennot-Dinet et al. 1990, Throndsen 1993) and to a lesser extent Raphidophyceae including Fibrocapsa sp. (Throndsen 1993), neither of which were observed in the convergence or subantarctic waters. In subantarctic waters the mean biovolume was significantly larger at $28.7 \mu^{3}$, due to the presence of Dinophyceans, Oxytoxum sp., Protoperidinium sp. and Gymnodinium sp. (Sournia 1986).

Ciliate numbers were highest in subantarctic waters with a mean of 1144 cells $\mathrm{l}^{-1}$, lower numbers were observed in convergence waters with a mean of

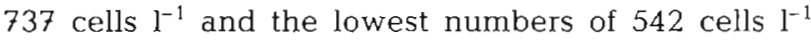
were observed in subtropical waters. Ciliate to HNF ratios were calculated based on $10 \mathrm{~m}$. Results varied between the 3 water masses; the highest mean ratio was observed in the convergence waters at $659: 1$, with subtropical waters at 559:1 and subantarctic waters having the lowest ratio at $404: 1$.

\section{Grazing experiments}

All phototrophic algal classes identified in this study, with the exception of Raphidophyceae and euglenophyceans, are reported to have members capable of phagotrophy (Borass et al. 1988). The genera belonging to these 2 classes were only found in subantarctic waters and consisted of Heterosigma, Fibrocapsa (Raphidophyceae) and Eutreptiella (Euglenophyceae). No individuals from these genera were found to exhibit phagotrophy, which concurs with the findings of Throndsen (1993) and Sanders (1991).

MNF clearance rates per individual in convergence and subantarctic waters were calculated using the total phototrophic algal population. This calculation may have been an underestimation of mixotrophic grazing on a per individual basis as uptake rate per individual was averaged over both individuals that grazed and those who did not. This calculation was based on the assumption that individuals of the same species, when found in a relatively homogeneous environment, should express a similar mixotrophic capacity. We therefore calculated a mean uptake rate per individual based on the premise that all genera that exhibited mixotrophy were mixotrophic. The non-mixotrophic genera in subtropical waters were estimated to represent $-10 \%$ of the phototrophic algae present in this water mass, so MNF clearance 
rates were calculated using only $90 \%$ of the total phototrophic algal population.

Despite their lower clearance rates per individual, the MNF populations contributed $55 \%$ of measured grazing on FLB, $40 \%$ of grazing on bacteria-sized artificial particles and $57 \%$ of grazing on picophytoplankton-sized particles due to their greater abundance than HNF.

Nanoflagellate uptake of FLB, and 0.5 and $1.0 \mu \mathrm{m}$ fluorescently labelled beads occurred at all stations. Grazing by both HNF and MNF populations was highest on FLB, with mean clearance rates across all water masses of 4.8 and $3.2 \mathrm{nl}$ ind. ${ }^{-1} \mathrm{~h}^{-1}$, respectively (Table 2). HNF uptake rates per individual on FLB were significantly higher (ANOVA $t=4.0, \mathrm{p}>0.001$ ) than MNF. Bacteria-sized particles were grazed at 2.5 and $0.9 \mathrm{nl}$ ind. ${ }^{-1} \mathrm{~h}^{-1}$ for $\mathrm{HNF}$ and MNF, respectively. HNF uptake rates for bacteria were also significantly higher $(t=3.9, \mathrm{p}>0.001$ ) than MNF uptake rates per individual (Table 2). Both HNF and MNF had higher clearance rates on picophytoplankton-sized particles than bacteria-sized particles when grazing on artificial prey, with clearance rates on picophytoplankton-sized particles of 4.2 and $3.5 \mathrm{nl}$ ind.$^{-1} \mathrm{~h}^{-1}$, respectively. HNF uptake rate was again significantly higher $(t=3.9, \mathrm{p}>$ 0.03) than MNF uptake rates per individual. We observed a high degree of variability in clearance rates between depths both within and across water masses. Consequently, we found no statistically significant changes in clearance rates between depths.

The proportion of the standing crop of bacteria removed per day by the total nanoflagellate population was highest using FLB as a tracer. Across all water masses FLB represented a removal rate of $11.0 \% \mathrm{~d}^{-1}$ of standing crop (Table 3). Stained bacteria were removed by HNF at rates ranging from 3.5 to $11.6 \%$ of the standing crop per day in subantarctic waters, 4.3 to $12.2 \%$ in convergence waters and 1.3 to $8.9 \%$ in sub-

Table 2. Mean nanoflagellate clearance rates and standard errors over all depths at which experiments were conducted in the 3 water masses. FLB: fluorescently labelled bacteria

\begin{tabular}{|c|c|c|c|}
\hline & Subantarctic & Convergence & Subtropical \\
\hline $\begin{array}{l}\text { MNF } 1.0 \text { bead } \\
\left(\mathrm{nl} \text { ind } .^{-1} \mathrm{~h}^{-1}\right)\end{array}$ & $2.25 \pm 0.29$ & $3.43 \pm 0.99$ & $2.58 \pm 0.33$ \\
\hline $\begin{array}{l}\text { HNF } 1.0 \text { bead } \\
\text { (nl ind. }{ }^{-1} \mathrm{~h}^{-1} \text { ) }\end{array}$ & $3.23 \pm 0.29$ & $5.23 \pm 0.80$ & $4.05 \pm 0.55$ \\
\hline $\begin{array}{l}\text { MNF } 0.5 \text { bead } \\
\text { (nl ind } .^{-1} h^{-1} \text { ) }\end{array}$ & $0.92 \pm 0.09$ & $1.26 \pm 0.22$ & $0.57 \pm 0.09$ \\
\hline $\begin{array}{l}\text { HNF } 0.5 \text { bead } \\
\text { (nl ind }{ }^{-1} h^{-1} \text { ) }\end{array}$ & $2.37 \pm 0.29$ & $2.62 \pm 0.61$ & $2.52 \pm 0.27$ \\
\hline $\begin{array}{l}\text { MNF FLB } \\
\left(\mathrm{nl} \text { ind } .^{-1} \mathrm{~h}^{-1}\right)\end{array}$ & $3.15 \pm 0.29$ & $3.53 \pm 0.55$ & $2.68 \pm 0.31$ \\
\hline $\begin{array}{l}\text { HNF FLB } \\
\text { (nl ind. }{ }^{-1} \mathrm{~h}^{-1} \text { ) }\end{array}$ & $6.03 \pm 0.47$ & $4.45 \pm 0.57$ & $3.99 \pm 0.54$ \\
\hline
\end{tabular}

tropical waters. The proportion of the standing crop of bacteria removed per day by the MNF populations, using FLB, was similar to HNF, with removal rates ranging from 4.5 to $13.9 \%$ in subantarctic waters, 2.8 to $13.4 \%$ in convergence waters and 1.62 to $5.9 \%$ in subtropical waters (Table 3 ).

The mean removal rate of standing crop using bacteria-sized $(0.5 \mu \mathrm{m})$ fluorescently labelled beads per day by the total nanoflagellate population was much lower than observed using FLB at $4.2 \%$. Bacteria-sized fluorescently labelled beads were removed by HNF at rates ranging from 1.0 to $6.7 \%$ of the standing crop per day in subantarctic waters, 0.8 to $6.4 \%$ in convergence waters and 0.1 to $3.0 \%$ in subtropical waters (Table 3 ). The proportion of the standing crop of bacteria removed per day by the MNF population was lower, with rates ranging from 0.7 to $5.1 \%$ in subantarctic waters, 0.3 to $4.3 \%$ in convergence waters and 0.1 to $1.6 \%$ in subtropical waters (Table 3 ).

The mean removal rate of picophytoplankton standing crop per day across all 3 water masses by the total nanoflagellate population using $1.0 \mu \mathrm{m}$ fluorescently labelled beads was $9.5 \%$. The proportion of the standing crop of picophytoplankton removed per day by the HNF population was double the removal of bacteriasized $(0.5 \mu \mathrm{m})$ fluorescently labelled beads, with rates of removal ranging from 1.2 to $7.5 \%$ in subantarctic waters, 0.9 to $7.6 \%$ in convergence waters and 0.4 to $5.9 \%$ in subtropical waters. The proportion of the standing crop of picophytoplankton removed per day by the MNF population was higher, with rates of removal ranging from 0.1 to $12.4 \%$ in subantarctic waters, 1.4 to $19.5 \%$ in convergence waters and 0.6 to $7.6 \%$ in subtropical waters (Table 3 ).

\section{DISCUSSION}

\section{Role of the microbial food web in the convergence zone}

The microbial food web has been reported to have a significant, but variable, role in the 3 water masses which make up the convergence zone off the east coast of New Zealand. Previous investigations in winter and spring reported that during both seasons in the subantarctic waters, and in the subtropical waters during spring, the microbial food web was the dominant pathway for carbon and energy flows (James et al. 1996, Hall et al. 1999, in this issue). During these periods the majority of phytoplankton biomass was found to be in the $<20 \mu \mathrm{m}$ size class and bacterial biomass dominated phytoplankton carbon (Hall et al. 1999). In this late summer study chl a was generally low, reflecting oligotrophic conditions (Table 1), and the majority of phyto- 
Table 3. Mean removal rates and standard errors for standing stock (SS) removal per day by HNF and MNF on bacterial and picophytoplankton populations calculated using clearance rates for FLB in 3 water masses

\begin{tabular}{|c|c|c|c|}
\hline & $\begin{array}{l}\text { Subantarctic } \\
\left(\% \text { removal } d^{-1}\right)\end{array}$ & $\begin{array}{l}\text { Convergence } \\
\left(\% \text { removal } \mathrm{d}^{-1}\right)\end{array}$ & $\begin{array}{c}\text { Subtropical } \\
\left(\% \text { removal d } d^{-1}\right)\end{array}$ \\
\hline \multicolumn{4}{|c|}{ Picophytoplankton } \\
\hline MNF 1.0 bead & $5.4 \pm 0.7$ & $6.1 \pm 1.7$ & $4.7 \pm 0.6$ \\
\hline HNF 1.0 bead & $3.3 \pm 0.3$ & $5.0 \pm 0.8$ & $3.7 \pm 0.5$ \\
\hline \multicolumn{4}{|l|}{ Bacteria } \\
\hline MNF 0.5 bead & $2.2 \pm 0.5$ & $2.2 \pm 0.5$ & $1.1 \pm 0.2$ \\
\hline HNF 0.5 bead & $2.4 \pm 0.3$ & $2.5 \pm 0.6$ & $2.3 \pm 0.4$ \\
\hline MNF FLB & $7.6 \pm 0.7$ & $6.3 \pm 1.0$ & $5.0 \pm 0.6$ \\
\hline HNF FLB & $6.2 \pm 0.5$ & $4.3 \pm 0.6$ & $3.7 \pm 0.5$ \\
\hline
\end{tabular}

ria-sized fluorescently labelled beads. The cause of this selectivity is likely to be have been 2 -fold; the variable size of FLB meant that, on average, they were larger than the natural population of bacteria, which could have led to selectivity by size as reported by Gonzales et al. (1990). Sherr et al. (1987) and Landry et al. (1991), however, reported significant selectivity between dead FLB and fluorescently labelled beads of the same size, with Sherr et al. (1987) reporting a maximum selectivity of 10 for dead FLB over fluorescently labelled beads and Landry et al. (1991) reporting a maximum of 20 for FLB over fluorescently labelled beads. Selectivity in the pre-

plankton biomass was in the $<20 \mu \mathrm{m}$ size class in all 3 water masses. In addition, between 30 and $70 \%$ of total phytoplankton biomass in the different water masses was contributed by picophytoplankton.

The ratio of bacterial carbon to phytoplankton carbon at a depth of $10 \mathrm{~m}$ was $4.5: 1$ in convergence waters, $2.8: 1$ in subantarctic waters and $2.7: 1$ in subtropical waters. Bacterial numbers across all 3 water masses were higher than previously reported in this region (Safi \& Hall 1997, Smith \& Hall 1997) and ranged from $1.6 \times 10^{6}$ to $2.9 \times 10^{6}$ (Table 1 ). These observations are similar to Cho \& Azam (1990), who report that in low chl a environments, bacterial carbon can often exceed phytoplankton carbon, commonly contributing 2 to 3 times the carbon of phytoplankton.

The biomass of the smaller prey (bacteria and picophytoplankton) in summer represented $-90 \%$ of the total combined bacterial and phytoplankton carbon, suggesting that the microbial food web dominates biological processes at this time. HNF, MNF and ciliates $<20 \mu \mathrm{m}$ are likely to be playing a pivotal role in the transfer of carbon and energy at this time (Bernard \& Rassoulzadegan 1990) as they are considered to be the primary grazers of both bacteria and picophytoplankton.

\section{HNF grazing}

Clearance rates by HNF measured on bacteria-sized artificial prey $(0.5 \mu \mathrm{m})$ across all water masses ranged from 0.1 to $12.3 \mathrm{nl}$ ind. ${ }^{-1} \mathrm{~h}^{-1}$ (mean $2.5 \mathrm{nl}$ ind..$^{-1} \mathrm{~h}^{-1}$ ), a larger range than previously reported in these waters during autumn by James et al. (1996) (0.03 to $7.9 \mathrm{nl}$ ind. ${ }^{-1}$ $\mathrm{h}^{-1}$, mean $0.32 \mathrm{nl}$ ind $\left.\mathrm{-}^{-1} \mathrm{~h}^{-1}\right)$ but similar to other experiments carried out by Hall et al. (1993), Cynar \& Sieburth (1986), Pace \& Bailiff (1987) and Sieraki et al. (1987).

Clearance rates measured for dead FLB in this study were on average much higher than those using $0.5 \mu \mathrm{m}$ fluorescently labelled beads, with a mean of $4.8 \mathrm{nl}$ ind..$^{-1} \mathrm{~h}^{-1}$ for FLB compared to $2.5 \mathrm{nl}$ ind..$^{-1} \mathrm{~h}^{-1}$ for bacte- sent study calculated by comparing the ratio of $\mathrm{HNF}$ clearance rates on $0.5 \mu \mathrm{m}$ fluorescently labelled beads to grazing on dead FLB resulted in a selectivity of 15 , mid-way between that reported by Sherr et al. (1987) and Landry et al. (1991). These results, although inconclusive, highlight the importance of prey selectivity.

For the first time in this region we identified the dominant HNF populations and found that Kinetoplastidea and Chrysophyceae classes dominated grazing in all 3 water masses. In subantarctic waters, high numbers of heterotrophic dinophyceans occurred (Table 1). Dinophyceans often have a preference for prey equal to their own size as opposed to other HNF, which have a preferred predator to prey ratio size of 3:1 (Hansen et al. 1994). Due to the different predator to prey ratio exhibited by dinoflagellates, for the first time we have evidence of how HNF species composition may influence grazing across the convergence zone.

\section{MNF grazing}

Photosynthetic nanoflagellate populations in all 3 water masses were dominated by the pyrmnesiophycean genera Chrysochromulina and Imantonia (Chretiennot-Dinet et al. 1990, Throndsen 1993), both of which exhibited the ability to ingest prey during our experiments. In addition, dinophyceans which represented a significant proportion of the photosynthetic nanoflagellate population in subantarctic waters were also observed to ingest prey. The dominance of these 2 classes in all 3 water masses indicates that the majority of photosynthetic nanoflagellate genera were capable of grazing at this time. These data highlight the importance of MNF during summer in terms of both their contributions to nanoflagellate populations and their grazing on bacteria and picophytoplankton. Despite the similarities between water masses, some clear distinctions could be observed. Subantarctic waters had the highest mean biovolume for MNF populations due 
to the presence of mixotrophic dinophyceans. Subtropical waters could also be clearly distinguished by the occurrence of non-mixotrophic genera from euglenophycean and raphidophycean classes. Taking this into account, MNF was still found to dominate nanoflagellate numbers, comprising $\sim 69.9,65.1$ and $63.3 \%$ of the total nanoflagellate population in subantarctic, convergence and subtropical waters, respectively.

MNF showed significantly higher clearance rates on FLB and $1.0 \mu \mathrm{m}$ fluorescently labelled beads compared to $0.5 \mu \mathrm{m}$ fluorescently labelled beads, with clearance rates on FLB ranging from 1.1 to $7.2 \mathrm{nl}$ ind ${ }^{-1} \mathrm{~h}^{-1}$ (mean $3.1 \mathrm{nl}$ ind.$^{-1} \mathrm{~h}^{-1}$ ). These results were lower than HNF but comparable to results from other experiments (Sanders 1991, Jones 1994). Despite this, the greater abundance of MNF meant they dominated the grazing impact on bacteria in all 3 water masses. MNF contributed $55 \%$ of the nanoflagellate grazing on FLB across all stations, $57 \%$ of the grazing on picophytoplankton-sized fluorescently labelled beads and $48 \%$ of the grazing on bacteria-sized fluorescently labelled beads. These results show the important link that MNF represent in the transfer of carbon and nutrients through the microbial food web in the convergence zone.

Grazing by the photosynthetically capable nanoflagellate populations is recognized to be energetically inefficient (Thingstad et al. 1996), which raises the question of why grazing occurred in the 3 different water masses investigated in this study. Salonen \& Jokinen (1988) suggested that MNF may be seeking inorganic nutrients, and more recent studies in the northern hemisphere have also shown that nutrient limitation stimulates mixotrophic grazing (Sibbald \& Albright 1991, Rothhaupt 1996b). Nutrients in both convergence and subtropical waters were at levels which could be considered as limiting to growth $\left(\mathrm{NO}_{3}\right.$ $\mathrm{N} 0.5$ and $0.2 \mu \mathrm{mol}$, respectively), and in subantarctic waters it has been suggested that micronutrients may control phytoplankton growth (Banse 1996, Hawes et al. 1997). We concede that other factors may be influencing the switch to grazing, but from the results of this study we suggest that MNF are likely to be seeking inorganic nutrients in these waters.

\section{Nanoflagellate grazing on bacterial standing stocks}

The combined grazing impact of HNF and MNF populations (total nanoflagellate grazing) on bacterial standing stock was greater in summer than previously observed in this region (Hall et al. 1993, James et al. 1996). Bacteria-sized fluorescently labelled beads in the current study gave an average total nanoflagellate removal rate of $4.3 \%$ of standing crop per day, with an even higher removal rate of $11.0 \%$ reported using FLB.
Both results were higher than previously reported by James et al. (1996) for autumn. The higher result for FLB could be an artefact of the larger size range of these prey and because of this we believe it is more appropriate to compare bacteria-sized fluorescently labelled beads with bacterial production in order to determine the overall impact of grazing.

In subtropical waters, bacterial production gave a specific growth rate of $16 \% \mathrm{~d}^{-1}$ and an estimated grazing rate using bacteria-sized fluorescently labelled beads of $3.4 \%$ of standing stock per day (Table 3 ). Convergence waters had a specific growth rate of $12 \%$ $\mathrm{d}^{-1}$ and a grazing rate of $4.7 \%$ (Table 3 ), while subantarctic waters had a specific growth rate of $9 \% \mathrm{~d}^{-1}$ and a grazing rate of $4.6 \%$ of standing stock (Table 3 ). If the clearance rates on FLB do represent a more realistic estimate of grazing rates as suggested by the selectivity results of Sherr et al. (1987) and Landry et al. (1991), then in subantarctic waters FLB with an estimated grazing rate of $13.8 \%$ of standing stock per day could potentially be reducing the bacterial standing stock in these waters. All these values, although higher than previously reported for this region, are within the range reported in studies elsewhere. Fenchel (1982c) reported removal of 10 to $70 \%$ of production, Anderson \& Fenchel (1985) reported between 5 and $250 \%$ removal and McManus \& Fuhrman (1986), using bacteria-sized fluorescently labelled beads, reported more than $96 \%$ removal of the $<1 \mu \mathrm{m}$ fraction. By accounting for a significant proportion of the bacterial production in all 3 water masses, these results again highlight the importance of grazing by nanoflagellates within the microbial loop in summer.

\section{Impact of nanoflagellate grazing on picophytoplankton standing stocks}

Picophytoplankton in this study represent the second most abundant source of prey for nanoflagellates and appear to play an important role in the microbial food web in all water masses. HNF and MNF clearance rates were higher on picophytoplankton-sized fluorescently labelled beads than on bacteria-sized fluorescently labelled beads in all water masses, suggesting that picophytoplankton-sized fluorescently labelled beads were being selectively grazed (Table 2). This result agrees with James et al. (1996), who also reported a preference for picophytoplankton-sized fluorescently labelled beads over bacteria-sized fluorescently labelled beads in these waters. However, clearance rates calculated on 1.0 $\mu \mathrm{m}$ particles are also likely to have been influenced by the higher tracer density used in these experiments, thus making direct comparisons difficult to interpret. In the present study the removal of standing crop by the total 
nanoflagellate population was $9.4 \%$. This rate was higher but within the range observed by James et al. (1996), who reported clearance rates from 0.2 to $15.7 \%$ $\mathrm{d}^{-1}$, and was also similar to removal rates reported in similar studies (Sanders et al. 1989, Berninger et al. 1991b, Kuosa 1991, Christoffersen 1994).

When we consider the individual water masses, we find that the observed removal rates using $1.0 \mu \mathrm{m}$ fluorescently labelled beads account for only a small proportion of the prokaryotic picophytoplankton production. The specific growth rate of the $<2 \mu \mathrm{m}$ size fraction of chl $a$ in subtropical waters was $70 \% \mathrm{~d}^{-1}$, with $~ 8.7 \%$ of standing stock per day grazed by nanoflagellates (Table 3). Convergence waters had a specific growth rate of $58 \% \mathrm{~d}^{-1}$ and a grazing rate of $8.4 \%$ (Table 3 ), and subantarctic waters had a specific growth rate of $54 \% \mathrm{~d}^{-1}$ and a grazing rate of $10.1 \%$ (Table 3 ). These results are within the range reported by James et al. (1996) but lower than results from dilution experiments conducted by James \& Hall (1998). The results indicate that the highest grazing pressure on standing stock occurred in subantarctic waters, where we also found the highest nanoflagellate numbers (Table 1). Overall, however, these results indicate that, unlike bacterial grazing, grazing by nanoflagellates has only a moderate impact on the potential daily production of prokaryotic picophytoplankton. Given that stained bacteria is reported to be selected over artificial bacteria-sized particles (Sherr et al. 1987, Landry et al. 1991), it is also likely that the use of artificial picophytoplankton-sized particles may result in an underestimation of grazing rates on picophytoplankton.

This study has identified both HNF and MNF as key grazers of bacteria and picophytoplankton populations in summer. The results also indicate that both HNF and MNF are key components in the transfer of bacterial and picophytoplankton biomass to higher trophic levels, with the observed clearance rates accounting for a high percentage of the bacterial production in all 3 water masses. The identification of MNF as having similar if not greater grazing potential to HNF indicates that both forms must be considered as being important in the transfer of carbon and nutrients in the microbial food web. This study also identifies for the first time the key nanoflagellate genera responsible for grazing in this region and begins the important process of linking composition to grazing rates. Overall, this work has highlighted the need to reassess our concepts of food web structure to allow a more flexible approach to organisms that have more than 1 potential mode of nutrition.

Acknowledgements. We thank the master and crew of the RV 'Giljanes', and S. Pickmere and G. Payne for their assistance with analytical work. We also thank M. James and C. Kemp for their helpful comments on the manuscript.

\section{LITERATURE CITED}

Anderson $P$, Fenchel $T$ (1985) Bacterivory by microheterotrophic flagellates in seawater samples. Limnol Oceanogr 30:198-202

Azam F, Fenchel T, Field JG, Grey JS, Meyer-Reil LA, Thingstad $F$ (1983) The ecological role of water column microbes in the sea. Mar Ecol Prog Ser 10:257-263

Banse K (1982) Cell volumes, maximal growth rates of unicellular algae and ciliates, and the role of ciliates in the marine pelagial. Limnol Oceanogr 27:1050-1058

Banse K (1996) Low seasonality of low concentrations of surface chlorophyll in the subantarctic water ring: underwater irradiance, ion, or grazing? Prog Oceanogr 37:241-291

Bernard C, Rassoulzadegan F (1990) Bacteria of microflagellates as a major food source for marine ciliates: possible implications for the microzooplankton. Mar Ecol Prog Ser 64:147-155

Berninger UG, Finlay BJ, Kuuppo Leinikki P (1991a) Protozoan control of bacterial abundances in freshwater. Limnol Oceanogr 36:139-147

Berninger UG, Sanders RW, Finlay BJ (1991b) Heterotrophic flagellates of planktonic communities, their characteristics and methods of study. In: Patterson DJ, Larson J (eds) The biology of free-living heterotrophic flagellates. Systematics Association Spec Vol No. 45. Clarendon Press, Oxford, p $39-56$

Bird DF, Kalff J (1986) Bacterial grazing by planktonic lake algae. Science 231:493-495

Bloem J, Bar-Gilissen MB, Cappenberg TE (1986) Fixation counting a manipulation of heterotrophic nanoflagellates. Appl Environ Microbiol 52:1266-1272

Borass ME, Estep KW, Johnson PW, Sieburth JMcN (1988) Phagotrophic phototrophs: the ecological significance of mixotrophy. J Protozool 35:249-252

Caron DA, Lim EL, Miceli G, Waterbury JB, Valosis FW (1991) Grazing and utilisation of chlorococcoid and heterotrophic cyanobacteria and heterotrophic bacteria by protozoa in laboratory cultures and a coastal plankton community. Mar Ecol Prog Ser 76: 205-217

Chang FH (1988) Distribution, abundance, and size composition of phytoplankton off Westland, New Zealand, February 1982. NZ J Mar Freshwat Res 22:345-367

Cho BC, Azam F (1990) Biogeochemical significance of bacterial biomass in the ocean's euphotic zone. Mar Ecol Prog Ser 63:253-259

Chretiennot-Dinet M, Billard C, Sournia A (1990) Atlas du phytoplankton marin, Vol III. Chorarachniophycées, Chlorophycées, Chrysophycées, Cryptophycées, Euglenophycées, Eustigmatophycées, Prasinophycées, Prymnesiophycées, Rhodophycées et Tribophycées. CNRS, Paris

Christoffersen K (1994) Variation of feeding activities of heterotrophic nanoflagellates on picoplankton. Mar Microb Food Webs 8(1-2):111-123

Cynar FJ, Sieburth JMCN (1986) Unambiguous detection and improved quantification of phagotrophy in apochlorotic nanoflagellates using fluorescent microspheres and concomitant phase contrast and epifluoresent microscopy. Mar Ecol Prog Ser 32:61-70

Fenchel T (1982a) Ecology of heterotrophic microflagellates. I. Some important forms and their functional morphology. Mar Ecol Prog Ser 8:211-223

Fenchel T (1982b) Ecology of heterotrophic microflagellates. II. Bioenergetics and growth. Mar Ecol Prog Ser 8:225-231

Fenchel T (1982c) Ecology of heterotrophic microflagellates. IV. Quantitative occurrence and importance of bacterial consumers. Mar Ecol Prog Ser 9:35-42 
Gonzales JM, Sherr, EB Sherr BF (1990) Size-selective grazing on bacteria by natural assemblages of estuarine flagellates and ciliates. Appl Environ Microbiol 56:583-589

Hall HA (1991) Long-term preservation of picophytoplankton for counting by fluorescence microscopy. Br Phycol J 26 : $169-174$

Hall JA, Barrett DP, James MR (1993) The importance of phytoflagellate, heterotrophic flagellate and ciliate graz. ing on bacteria and picophytoplankton-sized prey in a coastal marine environment. J Plankton Res 15:1075-1086

Hall JA, James MR, Bradford-Grieve JM (1999) The structure and dynamics of the microbial food web in the surface mixed layer of the subtropical convergence region off the east coast of New Zealand. Aquat Microb Ecol 20:95-105

Hansen B, Hansen PJ, Bjornsen PK (1994) The size ratio between planktonic predators and their prey. Limnol Oceanogr 39:395-403

Havskum H, Hansen AS (1997) Importance of pigmented and colourless Nano-sized protists as grazers on nanoplankton in a phosphate-depleted Norwegian fjord and in enclosures. Aquat Microb Ecol 12:139-151

Hawes I, Gall M, Weatherhead M (1997) Photosynthetic parameters in water masses in the vicinity of the Chatham Rise, South Pacific Ocean, during late summer. NZ J Mar Freshwat Res 31:25-38

Heath RA. (1985) A review of the physical oceanography of the seas around New Zealand 1982. NZ J Mar Freshwat Res 19:79-124

Hobbie JE, Dally RJ, Jasper S (1977) Use of nuclepore filters for counting bacteria by fluorescence microscopy. Appl Environ Microbiol 33:1225-1228

James MR, Hall JA (1995) Planktonic ciliated protozoa: their distribution and relationship to environmental variables in a marine coastal ecosystem. J Plankton Res 17:659-683

James MR, Hall JA (1998) Microzooplankton grazing in different water masses associated with the subtropical convergence round the South Island, New Zealand. Deep-Sea Res I 45:1689-1707

James MR, Hall JA, Barrett DP (1996) Grazing by protozoa in marine coastal and oceanic ecosystems off New Zealand. NZ J Mar Freshwat Res 30:313-324

Jansson M, Blomqvist P, Jonsson A, Bergstrom A (1996) Nutrient limitation of bacterioplankton, autotrophic and mixotrophic phytoplankton, and heterotrophic nanoflagellates in lake Ortrasket. Limnol Oceanogr 41:1552-1559

Jones RI (1994) Mixotrophy in planktonic protists as a spectrum of nutritional strategies. Mar Microb Food Webs 8:87-96

Kuosa H (1991) Picoplanktonic algae in the northern Baltic Sea: seasonal dynamics and flagellate grazing. Mar Ecol Prog Ser 73:269-276

Landry MR, Lehner-Fournier JM, Sundstrom JA, Fugerness UL, Selph KE (1991) Discrimination between living and heat-killed prey by a marine zooflagellate Paraphysomonas vestita (Stokes). J Exp Mar Biol Ecol 146:131-151

Li WKW, Dickie PM, Irwin BD, Wood AM (1992) Biomass of bacteria, cyanobacteria, prochlorophyte and photosynthetic eukaryotes in the Sargasso Sea. Deep-Sea Res 39: $501-519$

Marrase C, Lim EL, Caron DA (1992) Seasonal and daily changes in bacterivory in a coastal plankton community. Mar Ecol Prog Ser 82:281-289

McManus GB, Fuhrman JA (1986) Bacterivory in seawater studied with the use of inert fluorescent particles. Limnol Oceanogr 31:420-426

Pace ML, Bailiff MD (1987) Evaluation of fluorescent micros- phere technique for measuring the grazing rate of phagotrophic organisms. Mar Ecol Prog Ser 40:185-193

Patterson DJ, Larson J (eds) (1991) The biology of free-living heterotrophic flagellates. Systematics Association Spec Vol No. 45. Clarendon Press, Oxford

Porter KG, Sherr EB, Sherr BF, Pace M, Sanders RW (1985) Protozoa in planktonic food webs. J Protozool 32:409-415

Rothhaupt KO (1996a) Laboratory experiments with a mixotrophic chrysophyte and obligately phagotrophic and phototrophic competitors. Ecology 77:716-724

Rothhaupt KO (1996b) Utilisation of substitutable carbon and phosphorus sources by the chrysophyte Ochromonas sp Ecology 77:706-715

Safi KA, Hall JA (1997) Factors influencing autotrophic and hetertrophic nanoflagellate abundance in five water masses surrounding New Zealand. NZ J Mar Freshwat Res 31:51-60

Salonen W, Jokinen S (1988) Flagellate grazing on bacteria in a small dystrophic lake. Hydrobiolgia 161:303-309

Sanders RW (1991) Trophic strategies among heterotrophic flagellates. In: Patterson DJ, Larson J (eds) The biology of free-living heterotrophic flagellates. Systematics Association Spec Vol No. 45. Clarendon Press, Oxford, p 21-38

Sanders RW, Porter KG (1988) The fate of bacteria: microbial and raphodynamics in freshwater and marine habitats. EOS 69:1112-1119

Sanders RW, Porter KG, Bennett SJ, De Biase AE (1989) Seasonal patterns of bacterivory by flagellates, ciliates, rotifers and cladocerans in a freshwater planktonic community. Limnol Oceanogr 34:673-687

Sanders RW, Porter KG, Caron DA (1990) Relationship between phototrophy and phagotrophy in the mixotrophic chrysophte Paterioochromonas malhamensis. Microb Ecol 19:97-109

Sherr EB, Sherr BF, Fallon RD (1987) Use of monodispersed, fluorescently labelled bacteria to estimate in situ protozoan bacterivory. Appl Environ Microbiol 53:956-965

Sibbald MJ, Albright (1991) The influence of light and nutrients on phagotrophy by the mixotrophic nanoflagellate, Ochromonas sp. Mar Microb Food Webs 5:39-47

Sieraki ME, Hass LW, Caron DA, Lessard EJ (1987) Effect of fixation on particle retention by microflagellates: underes timation of grazing rates. Limnol Oceanogr 38:251-258

Smith R, Hall JA (1997) Bacterial abundance and production in different water masses around the South Island, New Zealand. NZ. J Mar Freshwat Res 31:515-524

Sournia A (ed) (1986) Atlas du phytoplankton marin, Vol 1 Cyanophycées, Dictyochophyées, Dinophycées and Raphidophycées. CNRS, Paris, p 219

Strickland JDH, Parsons TR (1972) A practical handbook of seawater analysis. Bull Fish Res Board Can 167

Thingstad TF, Havskum H, Garde K, Riemann B (1996) On the strategy of 'eating your competitor': a mathematical analysis of algae mixotrophy. Ecology 77:2108-2118

Throndsen J (1993) The planktonic marine flagellates. In: Thomas CR (ed) Marine phytoplankton: a guide to naked flagellates and coccolithophorids. Academic Press Inc, London, p 7-145

Vincent WF, Howard-Williams C, Tildesley P, Butler E (1991) Distribution and biological properties of oceanic water masses around the South Island, of New Zealand. NZ J Mar Freshwat Res 25:21-42

Wicks RJ, Robarts RD (1987) The extraction and purification of DNA labelled with [methyl-3H] thymidine in aquatic bacterial production studies. J Plankton Res 9:1167-1181 